\title{
Kontrol Suhu Otomatis Oven Vulkanisasi Konvensional di Laboratorium Unit Produksi Serabut Kelapa Berkaret
}

\section{Automatic Temperature Control of Conventional Vulcanization Oven in the Rubber Coir Production Unit Laboratory}

\author{
Nurjan Didik Purwanto, Puji Wiyono, Andika Wahyu P. \\ Jurusan Teknologi Pertanian, Politeknik Negeri Lampung \\ Jl. Soekarno Hatta, Rajabasa, Bandar Lampung 35144 Tel. (0721)703995 \\ Email :purwantonurjan@gmail.com
}

\begin{abstract}
The vulcanization process is a chemical reaction between rubber and sulfur to form cross-links and produce a three-dimensional structure. Temperature control in the vulcanization process is important to support the quality of the goods produced. In the coconut coir rubber production unit laboratory, the vulcanization oven is still conventional and manual for temperature control, therefore an operator is required to be on standby when the vulcanization oven is operated. The negligence of the operator will be fatal both in terms of the quality of the rubberised coir produced and the risk of fire. One of the causes of frequent fires in vulcanization ovens is the difficulty in setting the temperature in the oven process. To anticipate the occurrence of fires in the vulcanization oven, it is necessary to modify and add a temperature control to the oven. Based on the above problems, modifications need to be made which include the addition of a temperature control system and fire protection that combines temperature control, electric motor, fan, and indicator sirens in rubberized coconut fiber ovens so that the quality of the products produced remains good and avoids fire hazards. With this system, it is hoped that it can provide a sense of security and comfort for operators and contribute to the world of education, especially for students of the Agricultural Mechanization Study Program and other study programs at Lampung State Polytechnic. Automatic Temperature Control of Conventional Vulcanization Ovens in the Rubber Coir Production Unit Laboratory
\end{abstract}

Keywords: Fire protection system, and temperature limi, oven vulcanization, rubber coir

Naskah ini diterima pada tanggal 27 Oktober 2020, direvisi pada tanggal 10 Nopember 2020 dan disetujui untuk diterbitkan pada tanggal 15 Desember 2020

\section{PENDAHULUAN}

Serat Sabut Kelapa Berkaret (Rubberized Coir) merupakan produk kombinasi dari bahan baku serat sabut kelapa dengan karet alam yang telah divulkanisasi. Proses Vulkanisasi merupakan reaksi kimia antara karet dengan belerang, sehingga membentuk ikatan silang dan menghasilkan struktur tiga dimensi (Bhuana, 1990 dan Pujiastuti, 2007). Selain itu, menurut Meilani (2006) serat sabut kelapa berkaret merupakan serat keriting dari sabut kelapa yang dibalut dan diikat dengan karet dari lateks pekat. 
Pengembangan teknologi sabutret telah banyak dilakukan oleh institusi perguruan tinggi, seperti yang telah dilakukan di Unit produksi sabutret Politeknik Negeri Lampung, yang bertujuan untuk menunjang Tri Dharma Perguruan Tinggi.

Salah satu peralatan yang ada di unit produksi sabutret adalah "Oven Vulkanisasi", tetapi oven vulkanisasi yang ada di Unit Produksi Sabutret masih konvensional sehingga pada saat operasional, pengontrol suhunya masih memerlukan tenaga manusia untuk memantaunya, dengan cara menggurangi volume bahan bakar bio massanya di ruang tungku pembakaran. Ketika kondisi suhu di ruang oven vulkanisasi tinggi, dan jika kondisi ini berkelanjutan maka berpotensi menimbulkan bahaya kebakaran, dari masalah tersebut penulis mencoba mencari solusi untuk melakukan penelitian yang berjudul: "Pemasangan Kontrol Suhu Otomatis Sebagai Antisipasi Kebakaran Pada Oven Vulkanisas Konvensional di Laboratorium Unit Produksi Sabutret“. Dari penelitian ini diharapkan dapat memberikan kontribusi pada laboratorium tersebut sehingga dapat memperkecil tingkat bahaya kebakaran pada oven sabutret.

\section{Rumusan Masalah}

Salah satu penyebab sering terjadinya kebakaran pada oven vulkanisasi adalah sulitnya pengendalian suhu pada proses peng-ovenan, karena masih memerlukan tenaga manusia untuk mengontrolnya, dengan cara mengurangi volume bahan bakar (kayu, ranting, sekam padi sebagai bahan bakarnya) pada tungku oven atau pengendalian motor pendorong kipas (fan) dengan cara mematikanya, dengan sistem ini operator harus stand by di dalam ruangan saat oven vulkanisasi dioperasikan, terkadang operator lupa atau tertidur dan lalai ketika suhu pada oven vulkanisasi sudah tinggi, sehingga menimbulkan potensi kebakaran.

Untuk mengurangi tingkat kebakaran pada oven vulkanisasi diperlukan sedikit modifikasi dan penambahan pengontrolan suhu pada oven tersebut, dan dari permasalahan diatas maka penulis mencoba menuangkan ide kreatif untuk mengurangi permasalahan yang timbul ketika terjadi proses vulkanisasi pada oven tersebut.

Adapun rumusan masalah yang akan dituangkan penulis dalam penelitian ini adalah:

a. Menambah sistem pengontrolan suhu dan proteksi kebakaran pada Oven Vulkanisasi Sabutret sehingga penentuan suhu peng-ovenan terjaga sehingga mutu dari produk sabutret akan bagus.

b. Sistem keamanan pengontrolan suhu yang dikombinasikan dengan motor listrik kipas pendorong (fan) dan sirine indikator suhu. Sehingga operator mengetahui batas suhu pengovenan sudah tercapai ketika sirine berbunyi dan motor penggerak kipas (fan) akan mati secara otomatis.

c. Memperkenalkan salah satu metode sistem pengontrolan suhu pada oven vulkanisasi sabutret.

d. Memperkenalkan pada mahasiswa tentang pentingnya sistem pengontrolan suhu dan proteksi kebakaran, sehingga memudahkan serta memberikan rasa nyaman pada saat dioperasionalkan. 


\section{Tujuan Pembuatan Alat}

Tujuan pembuatan alat ini adalah:

a. Membuat sistem keamanan dan proteksi kebakaran pada oven vulkanisasi dengan menggunakan pengontrolan suhu secara otomatis.

b. Menguji system keamanan yang dibuat untuk oven vulkanisasi sabut kelapa berkaret.

\section{Manfaat Pembuatan Alat}

Manfaat yang diharapkan dalam pembuatan alat ini adalah sebagai berikut:

a.Membantu mengurangi risiko kebakaran yang disebabkan oleh tidak adanya sistem pengontrolan suhu pada oven vulkanisasi.

b. Membantu memperlancar proses belajar-mengajar bagi mahasiswa pada jurusan teknologi pertanian, budidaya tanaman perkebunan D3, D4 PMIP, dan Teknik Rekayasa Kimia Industri serta program studi lain yang ada di Politeknik Negeri Lampung.

c. Meningkatkan motivasi dan kreativitas bagi PLP dalam melaksanakan tugas pengelolaan laboratorium didalam menghadapi keterbatasan peralatan serta biaya yang tersedia.

d. Perbendaharaan peralatan praktikum dan sistem proteksi pada peralatan semakin bertambah serta tercapainya kualitas pembelajaran dan produksi.

e. Dengan banyaknya keragaman sistem proteksi peralatan di laboratorium tertutup dan terbuka diharapkan terbukanya wawasan mahasiswa dalam melaksanakan penelitian, Proyek Mandiri (PUM) dan dunia kerja.

\section{METODE PENELITIAN}

\section{Waktu dan Tempat}

Penelitian dan perancangan alat dilakukan di Laboratorium Mekanisasi Pertanian dan Laboratorium Pendidikan dan Unit Produksi Sabutret Politeknik Negeri Lampung yang dimulai bulan Juni dan direncanakan selesai pada bulan November 2020.

\section{Alat dan Bahan}

Alat dan instrumen yang digunakan terdiri dari:

Multitester

1. Solder Listrik

2. Bor Listrik

3. Tool box set

4. Press skun 
Bahan yang digunakan antara lain:

1. Kabel NYM 4 x 4 mm dan kabel NYA 2,5 mm

2. Termokopel

3. Kontrol Suhu

4. Sirine

5. Thermis 3 fase dan 1 fase

6. Kontaktor magnit

7. Skun Kabel

8. Pilot Lamp

9. Rel daya

10. Skun kabel danIsolasi

11. Mata Bor berbagai ukuran

12. Panel Box

13. Soket dan terminal sambung

\section{Prosedur Perancangan Pembuatan Alat}

\section{Studi Literatur}

Sebelum dilakukan perancangan dan pembuatan alat, dilakukan studi literatur melalui sumber-sumber yang dapat diakses seperti Perpustakaan Pusat Politeknik Negeri Lampung, dan Internet. Studi ini dilakukan untuk mencari informasi terkait hal-hal sebagai berikut:

a. Spesifikasi dan karakteristik peralatan dan bahan yang akan digunakan dalam penelitian dan perancangan sistem proteksi kebakaran dan pengontrolan suhu pada oven.

b. Karakteristik dan prinsip kerja oven konvensional.

c. Karakteristik dan prinsip kerja kontrol suhu (temperature controle) serta aplikasinya.

d. Karakteristik dan prinsip kerja termokopel dan aplikasinya.

\section{Spesifikasi Perancangan Alat}

Sistem Pemasangan kontrol suhu otomatis sebagai antisipasi kebakaran pada oven vulkanisasi konvensional sabutret yang dibuat merupakan desain sendiri yang perancangannya disesuaikan dengan box panel listrik yang telah ada dan tata letak serta kondisi oven konvensional yang ada di laboratorium pendidikan dan unit produksi sabutret, sehingga rancangan penelitian ini bisa direalisasikan.

\section{Pembuatan Alat}

Tahapan berikutnya setelah perancangan adalah pembuatan alat berdasarkan rancangan yang telah dibuat. Adapun beberapa proses yang dilakukan dalam tahapan ini adalah:

a. Menggambar desain rangkaian elektrik menggunakan komputer. 
b. Memplot hasil gambar rangkaian sebagai acuan dalam merangkai perakat elektriknya.

c. Memasang dan merangkai komponen elektrik pada panel serta pemasangan termokopel pada oven sabutret dan mengkombinasikan dengan box panel.

d. Membentuk konstruksi alat dan sistem proteksi kebakaran sesuai yang direncanakan.

\section{Pengujian Alat}

Tahapan yang terakhir dari pembuatan alat ini adalah pengujian alat dimana pengujian ini bertujuan untuk mengetahui alat yang dibuat berhasil atau tidak, dan apakah sesuai dengan desain spesifikasi perancangan peralatan proteksi yang diinginkan.

\section{HASIL DAN PEMBAHASAN}

\section{Realisasi Perancangan dan pengujian Alat}

\section{A. Realisasi Perancangan Alat}

Realisasi perancangan alat merupakan hasil akhir dari penelitian ini, realisasi perancangan alat yang dilakukan adalah mengaplikasikan desain gambar yang telah dibuat sebagai acuan untuk memasang dan merangkai komponen elektrik pada panel serta pemasangan termokopel pada oven vulkanisasi sabutret dan mengkombinasikan dengan box panel serta konstruksi alat dan sistem proteksi kebakaran sesuai yang direncanakan. Adapun realisasi perancangan alat penelitian ini dibagi menjadi 3 bagian pokok yaitu:

1. Realisasi desain gambar dalam perancangan Alat pengontrol suhu serta peletakan sensor suhu (thermocouple) pada oven sabutret.

Desain gambar dan perancangan alat yang dibuat disesuaikan dengan oven konvensional yang ada di laboratorium tersebut dimana pada perancangan ini dititik beratkan pada peletakan dan pemilihan sensor suhu, adapun sensor suhu yang digunakan adalah termokopel Tipe $\mathrm{K}$ dimana selain murah harganya termokopel ini umum digunakan, juga popularitas termokopel jenis ini tersedia dalam berbagai macam probe. Termokopel ini mempunyai rentang suhu diantara $-200^{\circ} \mathrm{C}$ sampai $+1200^{\circ} \mathrm{C}$ dan sensitivitasnya adalah berkisar $41 \mathrm{v} /{ }^{\circ} \mathrm{C}$. Adapun peletakan sensor suhu ini diletakan dekat dengan indikator suhu analog yang ada pada oven tersebut, Seperti yang tampak di bawah ini.

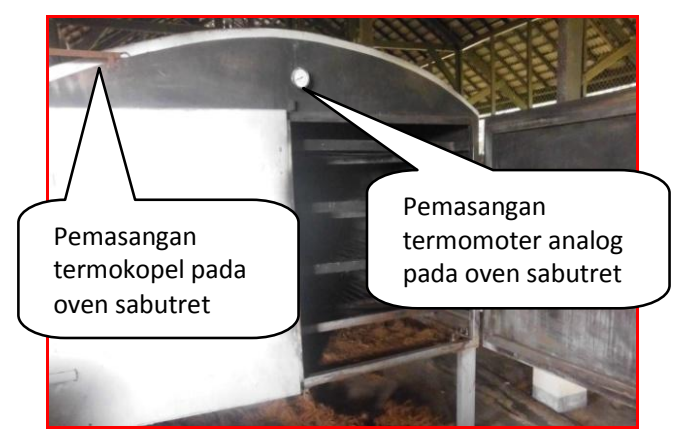

Gambar 1. Pemasangan dan peletakan sensor suhu (termokopel) pada oven sabutret. 
Dengan desain pemasangan seperti yang tampak pada gambar di atas diharapkan kesesuaian suhu ruang oven vulkanisasi pada saat peng-ovenan akan sama dengan termometer analog yang dipasang pada oven vulkanisasi tersebut sama dan tidak ada perbedaan.

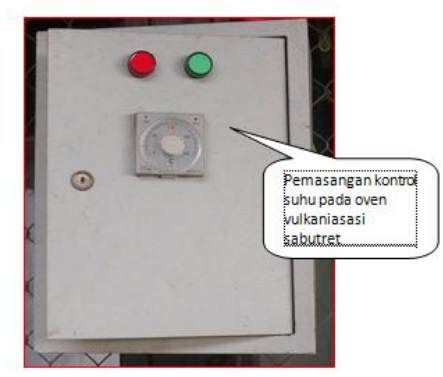

Gambar 2. Pemasangan dan peletakan kontrol suhu pada box panel proteksi.

Pada gambar di atas terlihat bahwa pemasangan kontrol suhu pada panel box kontrol diletakan di luar tutup box kontrol, hal ini dilakukan agar operator mudah saat setting suhu dan mudah pengontrolan pada saat oven dioperasionalkan.

2. Realisasi perancangan sistem proteksi kebakaran dan Panel box kontrol.

Sistem proteksi yang digunakan pada penelitian ini merupakan sistem keamanan tambahan yang didesain agar mudah dalam hal setting dan pengontrolan suhu sebagai antisipasi kebakaran pada saat oven dioperasionalkan serta memberikan rasa aman bagi operator.

Pada gambar di bawah terlihat bahwa desain oven sabutret masih konvensional dimana sistem pemanasannya masih menggunakan biomassa (kayu bakar) sebagai bahan bakar untuk menghidupkan tungku pemanasnya, ketika suhu ruang telah mencapai suhu yang telah diinginkan maka kipas pendorong dimatikan secara manual atau dikurangi volume bahan bakarnya (mengurangi kayu bakar) jika kipas dimatikan tetapi suhu masih melampui batas setting yang diinginkan.

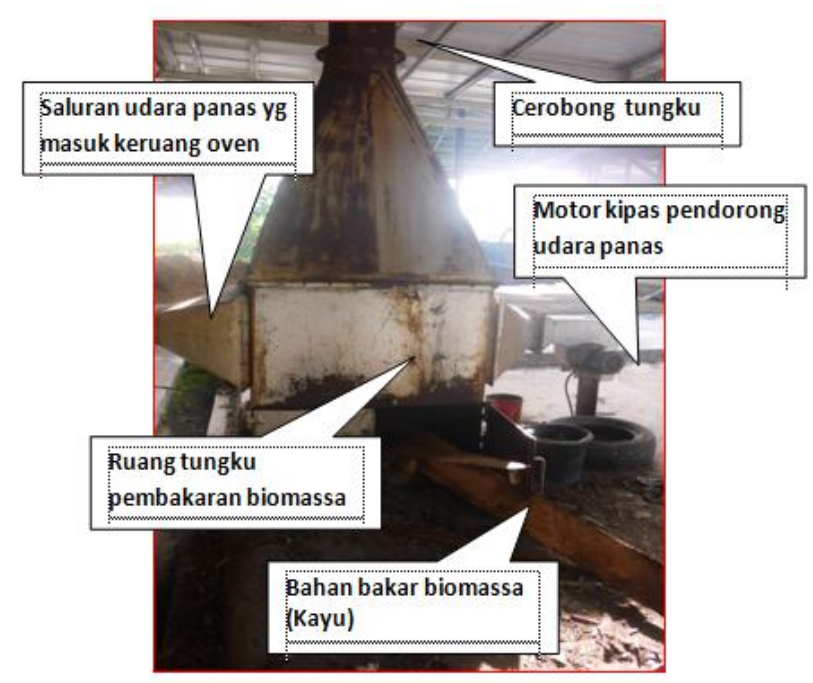

Gambar 3. Tungku oven konvensional sabutret dengan bahan bakar biomassa 


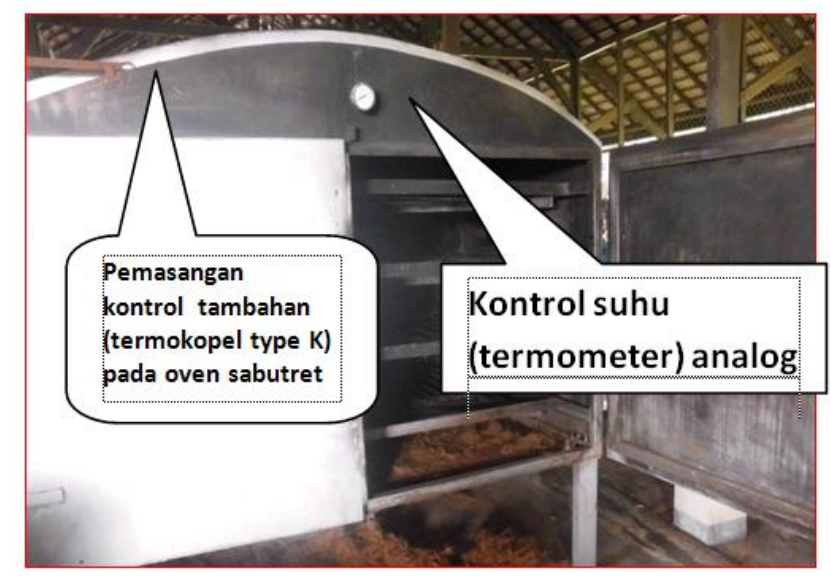

Gambar 4. Oven konvensional sabutret dengan bahan bakar biomassa

Pada gambar 3 dan 4 terlihat bahwa udara panas yang dihasilkan oleh tungku disalurkan melalui pipa persegi empat tahan panas ke dalam ruang oven dan sekaligus ditambah dengan kontrol suhu tambahan berupa termokopel type $\mathrm{K}$, seperti yang terlihat pada gambar 4.

Desain realisasi Panel box kontrol yang dibuat berdasarkan gambar acuan desain awal dimana pada panel tersebut terdapat kontaktor magnit yang berfungsi sebagai saklar elektrik mekanik penghubung dan pemutus daya listrik pada motor pendorong udara panas yang diatur oleh kontrol suhu sesuai dengan setting suhu pada ruang oven dengan cara memutar kearah kanan searah jarum jam sesuai dengan suhu yang dikehendaki.

Di dalam panel box tersebut juga terdapat Timer Delay Relay (TDR) yang berfungsi mengatur lamanya sirine berbunyi yang menandakan bahwa suhu setting telah tercapai dan kipas pendorong secara besamaan akan padam.

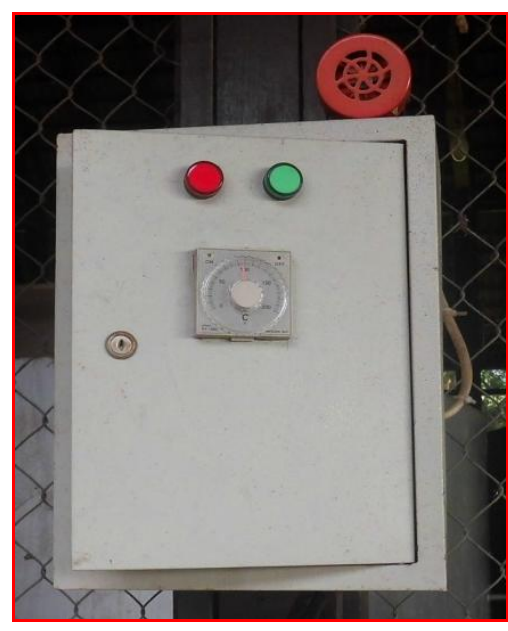

(a)

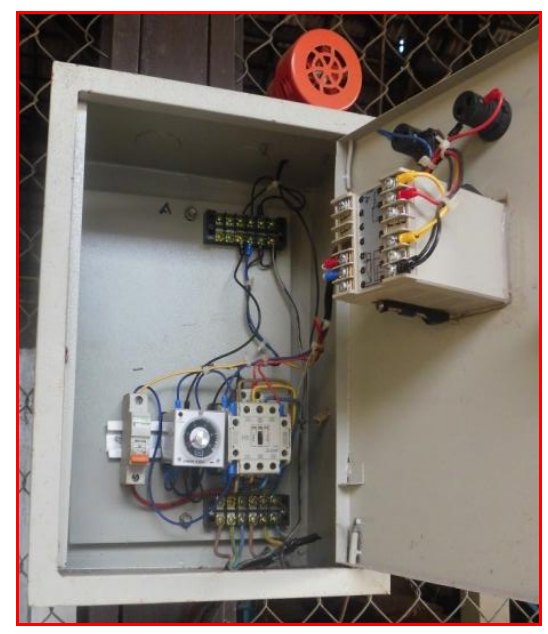

(b)

Gambar 5. Realisasi desain panel box kontrol (a) tampak bagian depan (b) tampak bagian dalam panel box kontrol. 
3. Realisasi keseluruhan sistem pengontrolan suhu, proteksi kebakaran dan kombinasi motor kipas pendorong serta sirine indikator suhu. Pada tahap ini merupakan penggabungan semua sistem proteksi yang telah rencanakan dan dibuat disesuaikkan dengan desain rancangan semula dan merupakan tahap akhir dari desain rancangan penelitian. Gabungan dari sistem yang dibuat diharapkan dapat meminimalisir kerusakan produksi dari hasil pengovenan dan memberikan rasa nyaman bagi operator dan terhindar dari bahaya kebakaran ketika oven dioperasionalkan. Adapun diagram pengawatan dari realisasi rancangan penelitian dapat dilihat pada gambar di bawah ini.

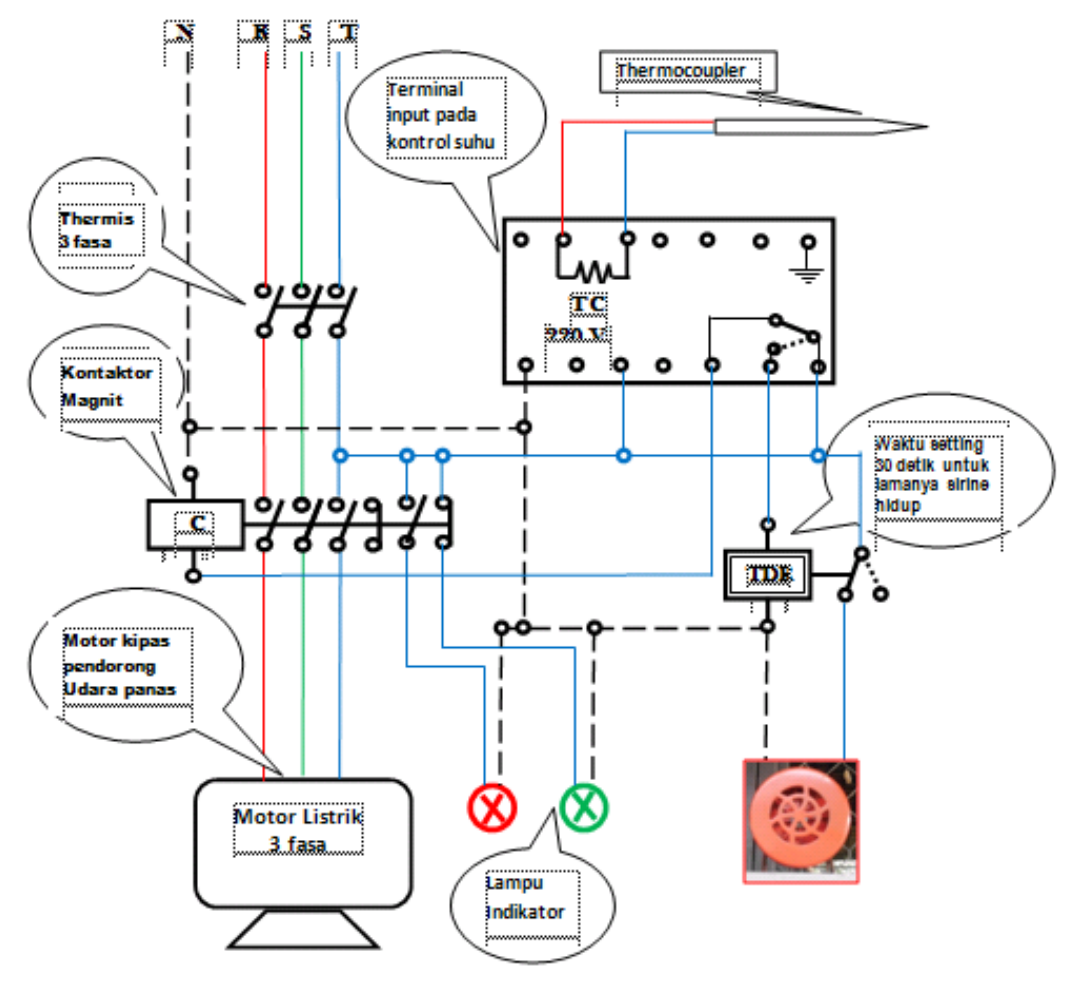

Gambar 6. Diagram pengawatan dari realisasi desain rancangan penelitian .

\section{B. Pengujian Hasil Perancangan Alat.}

Tahapan akhir dari penelitian ini adalah pengujian alat, sebelum melakukan pengujian tentunya dilihat dulu apakah rangkaian yang telah dibuat sesuai dengan desain awal apa belum. Karena faktor penentu dari berhasilnya penelitian ini tergantung dengan bekerjanya sensor suhu (termokopel) dan panel kontrol suhu maka perlu dilakukan pengujian terhadap hasil kerja perancangan alat. Pengujian alat di bagi menjadi 2 bagian antara lain;

1. Pengujian setting suhu pada kontrol suhu dan respon terhadap kipas pendorong udara panas.

Pengujian ini bertujuan untuk mengetahui perbedaan antara suhu setting dan suhu ruang oven vulkanisasi yang terbaca oleh termometer analog yang terpasang pada oven 
vulkanisasi, maka ketika tungku dinyalakan dan suhu disetting sebesar $100^{\circ} \mathrm{C}$, maka pada saat itu juga motor kipas pendorong akan hidup karena termokopel mendeteksi suhu pada ruangan oven masih dibawah batas suhu setting seperti yang tampak pada gambar di bawah ini.

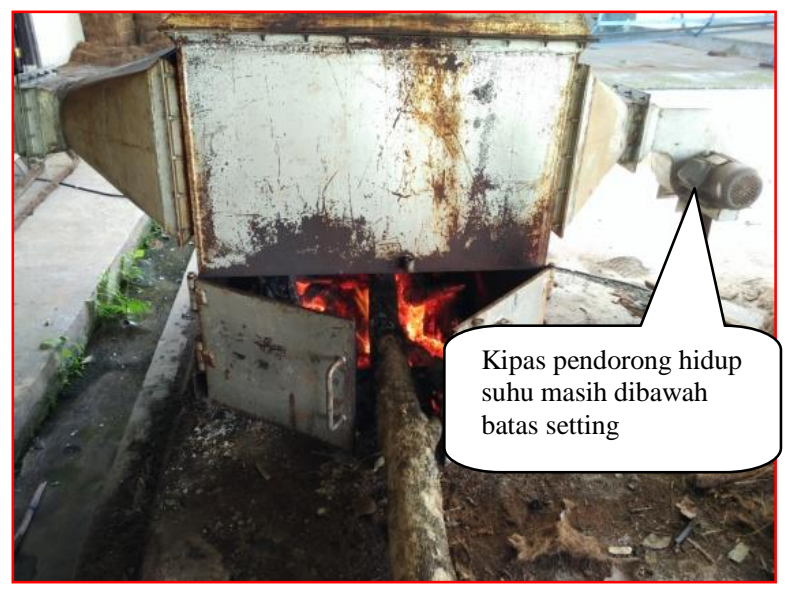

(a)

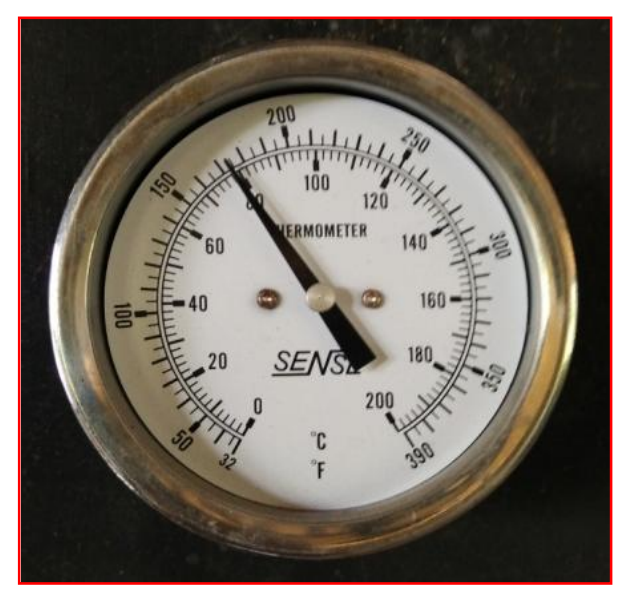

(b)

Gambar 7. (a) ketika tungku dipanaskan dan kipas pendorong masih hidup (b) suhu pada ruang oven masih $80^{\circ} \mathrm{C}$

Pada gambar $7(b)$ terlihat bahwa suhu pada ruang oven vulkanisasi masih $80^{\circ} \mathrm{C}$ sehingga motor kipas pendorong masih hidup dan ketika sampai pada batas setting suhu sebesar $101^{\circ} \mathrm{C}$ motor kipas pendorong mati.

Dari pengujian setting suhu pada kontrol suhu terdapat selisih $1^{\circ} \mathrm{C}$ hal ini wajar karena setiap produk alat kontrol terdapat toleransi pada produk yang dibuatnya, dan pengujian respon terhadap kipas pendorong udara panas ini selesai dan dinyatakan berhasil.

2. Pengujian setting suhu pada kontrol suhu dan respon Timer Delay Relay (TDR) untuk menghidupkan sirine.

Pengujian ini dilakukan untuk mengetahui reaksi TDR ketika suhu ruangan oven telah mencapai suhu setting, maka pada terminal NC input kontrol suhu akan berpindah menjadi terminal NO dan sistem ini dinamakan sistem interlock (jika salah satu sistem bekerja maka sistem yang lain mati), sehingga TDR bekerja untuk menghidupkan sirine sebagai indikator bahwa suhu diruang oven telah mencapai suhu setting, lama hidupnya sirine tergantung dari setting TDR yang kita inginkan, adapun diagram pengawatan sistem respon kontrol suhu terhadap reaksi TDR dapat dilihat pada gambar di bawah ini. 


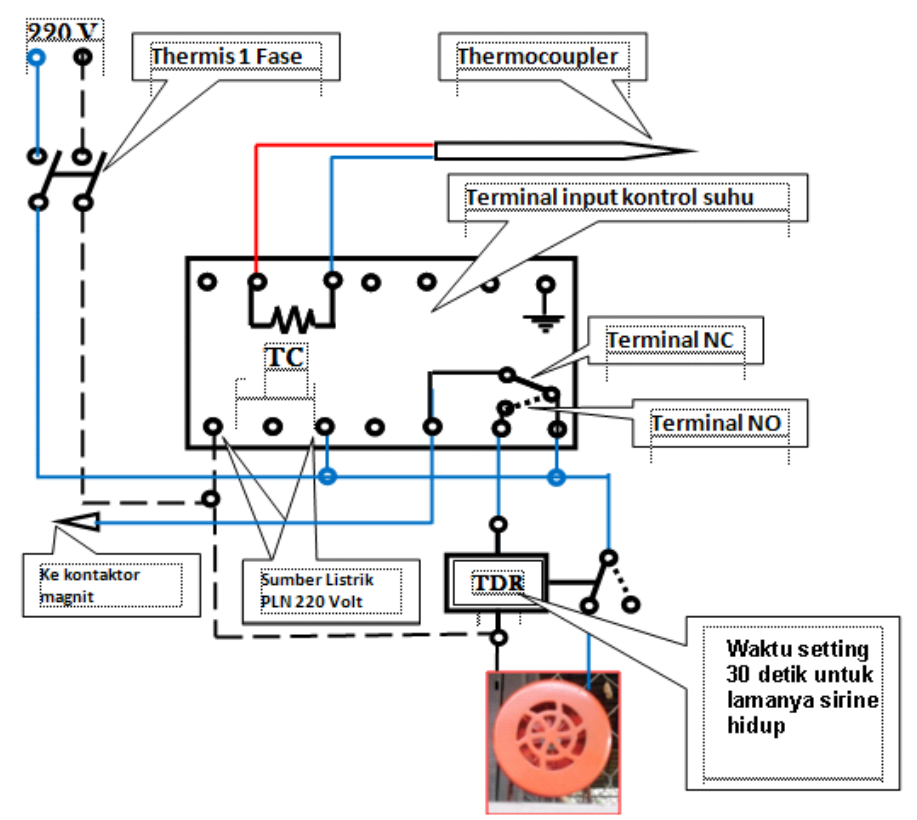

Gambar 8. Diagram pengawatan setting suhu pada kontrol suhu dan respon Timer Delay Relay (TDR) untuk menghidupkan sirine.

Dari diagram pengawatan di atas tampak bahwa jika suhu telah sampai pada batas setting maka sirine akan berbunyi dan kipas pendorong udara panas akan mati, dan dari keseluruhan pengujian yang telah dilakukan dapat disimpulkan bahwa sistem pemasangan kontrol suhu otomatis sebagai antisipasi kebakaran pada oven vulkanisasi berfungsi baik dan berhasil.

\section{KESIMPULAN DAN SARAN}

\section{Kesimpulan}

Dari beberapa pengamatan dan pengujian maka dapat disimpulkan;

1. Sistem keamanan dan proteksi kebakaran pada oven vulkanisasi sabut kelapa berkaret telah berhasil dibuat dengan memadukan pengatur suhu, motor listrik, kipas/blower dan indicator sirine sebagai peringatan.

2. Hidup dan matinya kipas pendorong udara panas tergantung pada batas setting suhu pada kontrol suhu, sistem pengontrolan pada panel suhu merupakan sistem interlock jika suhu dalan ruang oven tercapai maka kipas akan mati dan sirine langsung hidup, sistem akan bekerja secara otomatis meskipun operator tidak ada ditempat.

\section{Saran}

1. Karena sistem bekerja secara otomatis perlu pemeriksaan berkala pada sensor suhu (termokopel) karena sensor ini merupakan peralatan yang vital pada sistem ini.

2. Kerusakan pada sensor suhu (termokopel) akan berakibat fatal, karena suhu tak dapat dideteksi oleh kontrol suhu,sehingga dapat menyebabkan kebakaran. 
3. Operator harus selalu standby meskipun sistem proteksi kebakaran bekerja secara otomatis.

\section{DAFTAR PUSTAKA}

Anonymous, 2018 Modul Praktikum Energi Dan Listrik Pertanian, Tim ELP P.S. Mekanisasi Pertanian, Politeknik Negeri Lampung, Bandar Lampung 2018.

Pujiastuti L. 2007, skripsi: Pengaruh Waktu dan Suhu Vulkanisasi Pembuatan Kasur dari Serat Sabut Kelapa Berkaret. Institur Pertanian Bogor.

Prih Sumardjati, dkk. TEKNIK Pemanfaatan TENAGA LISTRIK Untuk Sekolah Menengah Kejuruan. Direktorat Pembinaan Sekolah Menengah Kejuruan, Direktorat Jenderal Manajemen Pendidikan Dasar dan menengah. Departemen Pendidikan Nasional Tahun 2008.

Purwanto N.D.2011, Skripsi: Rancang Bangun Pengaturan Bahan Bakar Pada Genset Hybrid (Bensin dan Bioetanol) Untuk Aplikasi Automatic Transfer Switch (ATS) Pada Listrik Rumah Tanggga. Universitas Lampung Bandar Lampung.

Purwanto N.D.2015, Penelitian PLP. ,“ Sistem Keamanan Elektrik (Electrical Security System) Sebagai Antisipasi K3 pada Laboratorium Instrumentasi dan kelistrikan Mekanisasi Pertanian Politeknik Negeri Lampung ",. 